\title{
Retrospective and Prospects for Cold Regions Landslide Research (2012-2016) (WCoE 2014- 2017, IPL-132, IPL-167, IPL-203, CRLN)
}

\author{
Wei Shan and Ying Guo
}

\begin{abstract}
For nearly 100 years, the average temperature of the global surface has showed a consistent warming trend. Climate change and extreme weather events causing landslides are rising, especially landslides in cold regions, and the topic has become a hot issue in landslide research. With the support of ICL and the Chinese government, based on highway construction projects in Heilongjiang Province (China), Prof. Shan and his group (Institute of Cold Regions Science and Engineering, North East Forestry University, China) conducted thematic studies focusing on environmental and engineering geology problems in cold regions in the context of climate change, such as IPL132, IPL167, and IPL203. These studies attracted the interest of international colleagues, then Chinese colleagues, together with researchers from Russia, Canada, Japan, Italy and Czech Republic, together organized the ICL-cold regions landslide network (ICL-CRLN). In ICL-CRLN researchers could exchange research information and results, and so promote the development of landslide research in cold regions. In 2014, IPL-GPC approved the establishment of IPL-WCoE: Research Center of Cold Regions Landslide, so landslide research in cold regions came into a new stage of development. This article is a summary and outlook of these activities.
\end{abstract}

\section{Keywords \\ Cold region landslides $•$ IPL projects - ICL-CRLN $•$ WCoE}

\section{Introduction}

For nearly 100 years, the average temperature of the surface of the globe has been showing a consistent warming trend. The rate of warming in the past 50 years is almost double that in the last 100 years (IPCC 2007). Since the early 1980s, the temperature of most permafrost regions has increased. In some places in northern Alaska, the observed warming rate reached $3{ }^{\circ} \mathrm{C}$, in the northern European region of Russia it reached $2{ }^{\circ} \mathrm{C}$ during 1975-2005, and it has been

W. Shan $(\square)$. Y. Guo

Institute of Cold Regions Science and Engineering, North East Forestry University, No.26 Hexing Road, Harbin, 150020, China e-mail: shanwei456@163.com

Y. Guo

e-mail: samesongs@163.com observed that the thickness and scope of permafrost has been significantly reduced (IPCC 2013). Today, climate change and its effects is a topic of widespread concern (Fig. 1).

The numbers of landslides caused by climate change and extreme weather events are rising (Blunden et al. 2011), and gradually gaining more attention of governments and international academic organizations (EU-FP7 2008; ICL 2014). Landslides in cold regions in particular have become a hot issue in landslide research (ICL 2012; Guo et al. 2013).

The mechanisms and evolution of landslides in mountainous areas are closely related to the geological conditions and environmental factors, and are controlled not only by geological forces, lithologic structure, and other crustal internal factors; but also by topography, land cover, precipitation, changes in human activities, and environmental conditions. The spatial and temporal distribution of 
Fig. 1 High-latitude permafrost distribution in Northeast China (data from Zurich University, Switzerland), and location of study area

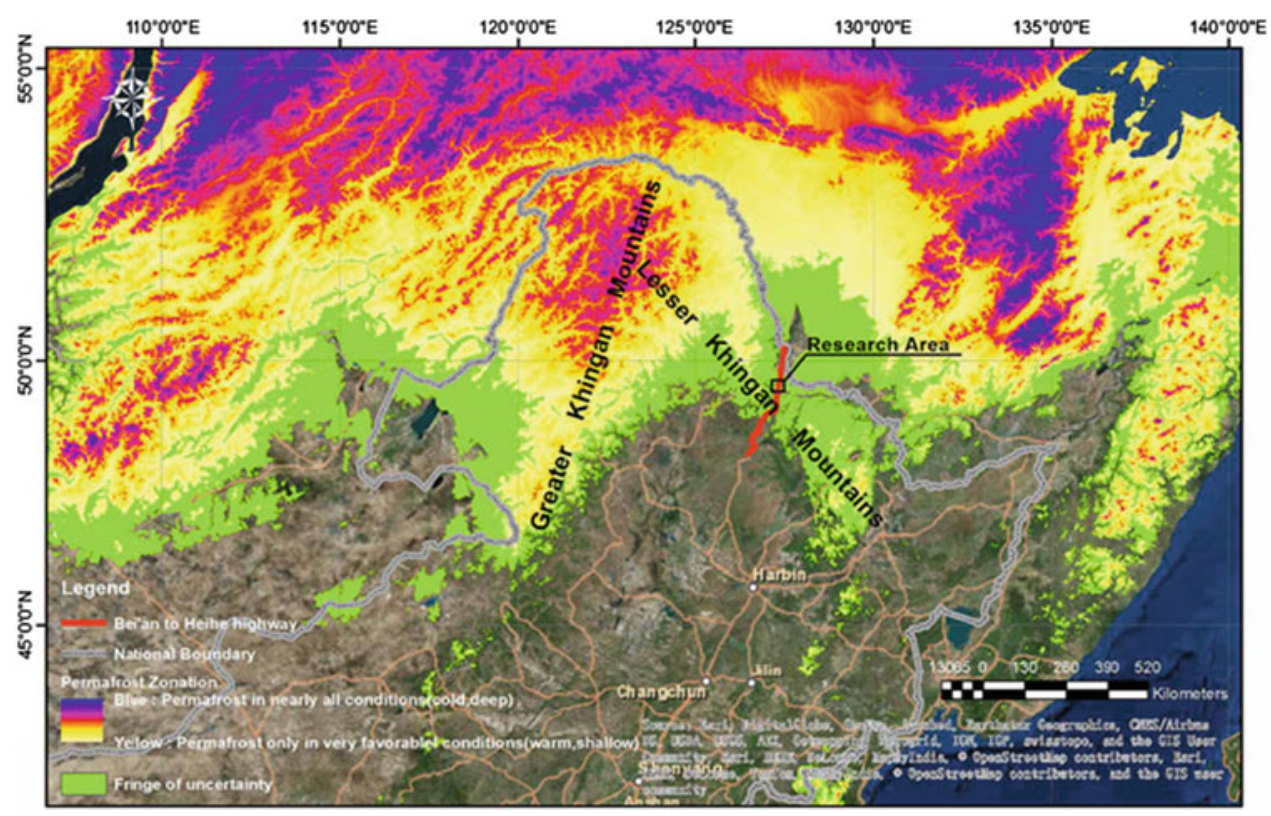

landslides is uncertain, sporadic in nature, continuous, and irreversible. Landslides are the result of geological and environmental changes and also drastically change the geological environment (Shan et al. 2014b). Scientists have used varying methods to analyze the relationships between climate change and landslide mechanisms and their evolution in cold areas (Shan et al. 2014a). The impact of landslides induced by glacier and permafrost degradation in cold regions on the topography, geological environment, water resources, and on biodiversity; and the role of climate, a main factor influencing landslide movement, in the evolution of landslides in cold areas have been studied (Fischer et al. 2013; Haeberli 2013; Kliem et al. 2013; Starnberger et al. 2013; Ballantyne et al. 2014; Graband Linde 2014; Nussbaumer et al. 2014). However, due to a lack of monitoring data, the majority of these studies were broad scale (Stoffel et al. 2014). Currently, there have been no reports on the mechanisms, movement characteristics, and patterns of landslides induced by the combined effect of permafrost thawing and extreme weather events due to climate change and geological conditions (Fig. 2).

\section{Relevant Organizations of ICL and Its Working Results}

With the support of ICL and the Chinese government, utilising highway construction projects in Heilongjiang Province(China), Prof. Shan and his group (Institute of Cold
Regions Science and Engineering, North East Forestry University, China) conducted a thematic study that focused on environmental and engineering geology problems in cold regions in the context of climate change, such as "Research on vegetation protection system for highway soil slope in seasonal frozen regions", "Landslides mechanism and the subgrade stability controlling measures in island permafrost area", "Analysis and identify of landslides based on species distribution and surface temperature difference"; those also are IPL projects. These studies attracted the interest of international and Chinese colleagues, with researchers from Russia, Canada, Japan, Italy and the Czech Republic together organizing an ICL-cold regions landslide network (ICL-CRLN), so researchers could exchange research information and results, and promote the development of landslide research in cold regions. In 2014, IPL-GPC approved the establishment of IPL-WCoE: Research Center of Cold Regions Landslide, which fostered a new stage of development for landslide research in cold regions (Fig. 3).

\section{Results of Regional Projects (IPL132, IPL167, IPL203)}

Project IPL132 focuses on shallow landslides caused by seasonal freeze-thaw in northeastern China, Project IPL167 focuses on landslides caused by permafrost degradation in permafrost regions of northeast China, and Project IPL203 focuses on environmental and ecological problems caused 


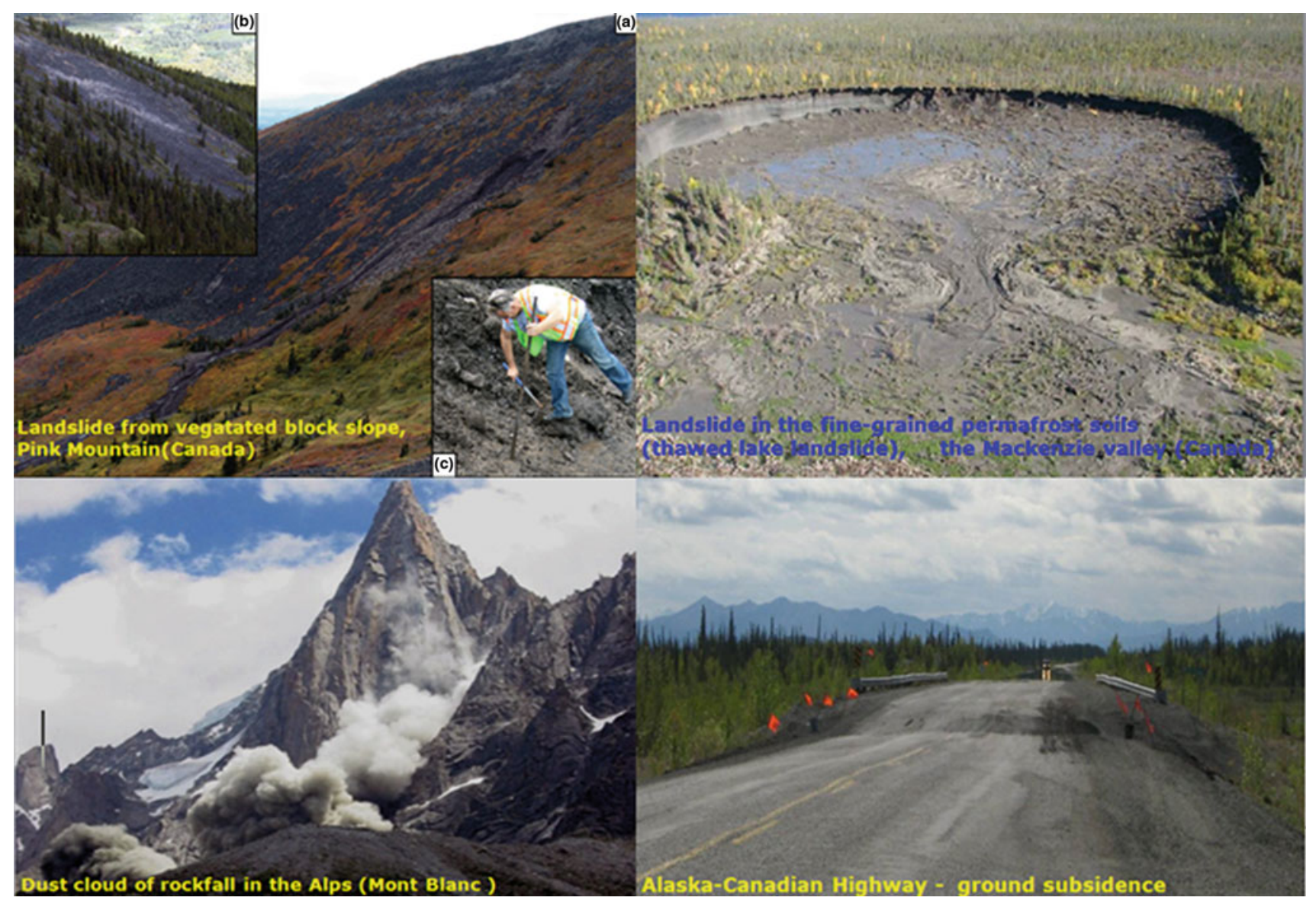

Fig. 2 Different forms of landslides around the world in cold regions

by permafrost degradation in permafrost regions of northeast China.

\section{IPL-132: Research on Vegetation Protection System for Highway Soil Slope in Seasonal Frozen Regions (Duration: 2008-2015)}

\section{Project leader:}

Prof. Wei Shan, Cold Regions Science and Engineering, Northeast Forestry University, Harbin, China.

Core members of the Project:

Dr. Fawu Wang, Shimane University, Japan

Dr. Ying Guo, Northeast Forestry University, China

Dr. Chengcheng Zhang, Northeast Forestry University, China

\section{Objectives:}

The study area is located along a major highway in China's Heilongjiang Province, the Kiamusze to Harbin sector of the Tong-San Expressway. This study aims to establish a comprehensive vegetation protection system for highway soil slopes in seasonally frozen regions. The system will aid in greening the regional environment along the highway, and in highway slope stabilization.

\section{Training Student: One doctor, Five Masters}

(1) Doctor Ying Guo. Mechanisms of slope freeze-thaw instability of cuttings and their protection by vegetation in high-latitude frozen regions (2013)

(2) Master Chengcheng Zhang. Research on stability and protection of shallow side slopes of soil road cuttings in seasonal frozen regions (2012)

(3) Master Chunming Liu. Research on the slope instability mechanism on freezing and thawing of the K560 +300 to K561+000 section of the Tongsan-Sanya highway (2013)

(4) Master Fuliang Wang. The evaluation to plant comprehensive protection systems along a high-grade highway in a seasonal frost area (2008) 
Fig. 3 Main research activities in cold regions

\begin{tabular}{|c|c|}
\hline \multirow{3}{*}{$\begin{array}{l}\text { Regional Projects } \\
\text { IPL132/IPL167/ IPL } \\
203\end{array}$} & Relying on highway construction projects in Heilongjiang Province(China) \\
\hline & $\begin{array}{l}\text { IPL } 132 \begin{array}{l}\text { Research on vegetation protection system for highway soil } \\
\text { slope in seasonal frozen regions }\end{array}\end{array}$ \\
\hline & $\begin{array}{l}\text { IPL } 167 \text { Landslides Mechanism and the Subgrade Stability Controlling } \\
\text { Measures in Island Permafrost Area } \\
\text { IPL } 203 \begin{array}{l}\text { Analysis and identify of landslides based on species } \\
\text { distribution and surface temperature difference }\end{array}\end{array}$ \\
\hline
\end{tabular}

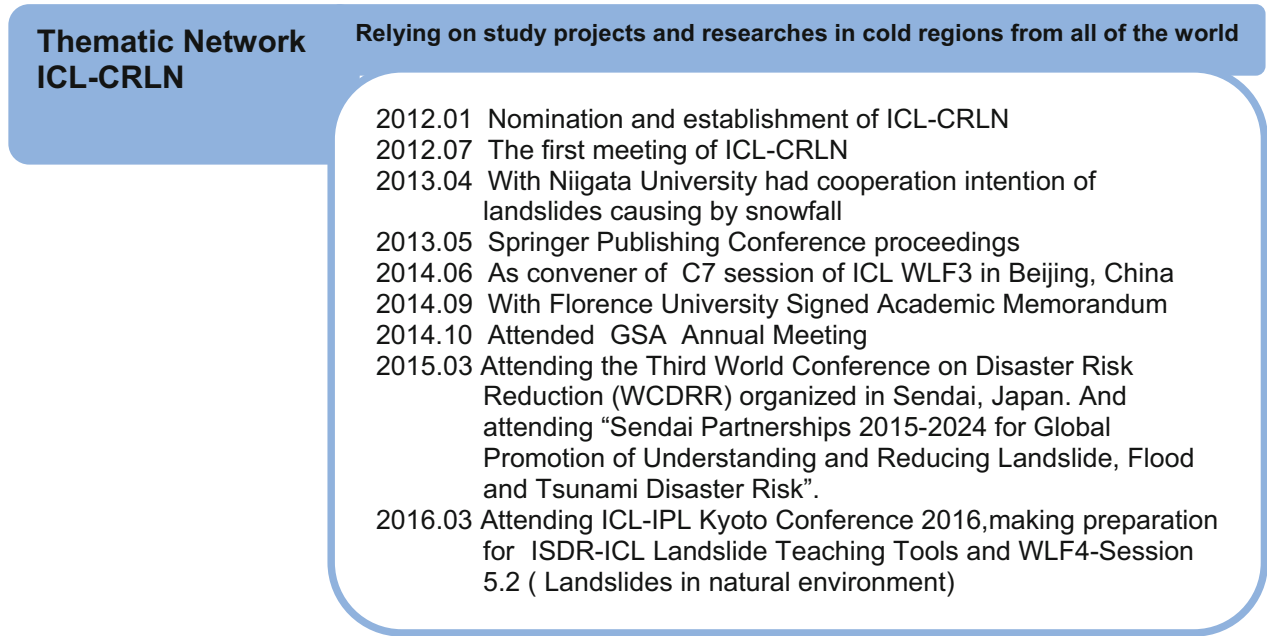

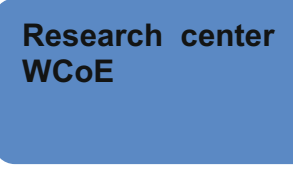

Based on the research results of IPL projects and the help of ICL-CRLN

2013.10 Nomination and establishment of WCoE- Research Center of Cold Regions Landslide

2014.09 As convener of 1.9 session of IAEG XII Congress in Turin, Italy

2014.10 Attended the Workshop "Impacts of permafrost thaw in mountain areas" in Canada

2015.10 With CAREERI (Cold and Arid Regions Environmental and Engineering Research Institute, CAS.); Nanjing Institute of Geography and Limnology, CAS.; Beijing Institute of Geographic Science and Natural Resources Research, CAS., reached cooperation agreements

2016.03 Seting up field observation stations in Heilongjiang and Inner Mongolia provinces, China.

(5) Master Yuying Sun. Study on mechanisms of plant protection of soil slopes on Heilongjiang Road (2008)

(6) Master Yao Liu. Establishment and experimental study of a frozen soil resistivity model (2015).

\section{Publications:}

1. Wei Shan, Wang Fawu, Liu Hongjun (2008) Cause Analysis on the Shallow Landslide of Highway Soil Cutting Slopes in Seasonally Frozen-Ground. First World Landslide Forum, 2008.

2. Wei Shan, Hongjun Liu, Lin Yang, Ying Guo (2008) Changes of soil moisture of Shallow Slope in seasonal frozen cutting slope. Rock and Soil Mechanics.
3. Wei Shan, Hongjun Liu, Ying Guo (2009) Effect of freeze-thaw on strength and microstructure of silty clay. Journal of Harbin Institute of Technology.

4. Wei Shan (2008) "Highway greening project" Northeast Forestry University Press.

5. Hongjun Liu, Ying Guo, Wei Shan et al. (2011) Instability of soil cutting slopes caused by freeze-thaw and reinforcement mechanism by vegetation Chinese Journal of Geotechnical Engineering. 08: 1197-1203.

6. Ying Guo, Wei Shan (2011) "Monitoring and Experiment on the Effect of Freeze-Thaw on Soil Cutting Slope Stability" Procedia Environmental Sciences 10: 11151121.

7. Ying Guo, Wei Shan et al. (2011) Landslides and Moisture - temperature for Cutting Slope soil in Freeze 
- thaw Cycles. Proceedings of the Second World Landslide Forum 3-7 October 2011, Rome.

8. Ying Guo, Wei Shan (2013) The Effect of Freeze-Thaw and Moisture on Soil Strength Index of Cutting Slope. Progress of Geo-Disaster Mitigation Technology in Asia, Environmental Science and Engineering, DOI:10. 1007/978-3-642-29107-4_20, Springer-Verlag.

9. Wei Shan, Fawu Wang et al. (2013) Shallow Slope Failure and Protection Method Along a Highway in a Seasonally Frozen Area in China. Progress of Geo-Disaster Mitigation Technology in Asia, Environmental Science and Engineering, DOI:10.1007/978-3642-29107-4_25, Springer-Verlag.

10. Shan Wei, Guo Ying et al. (2012) Effects of Soil Water Content and Density on Slope Reinforcement by Plant Roots Journal of Northeast Forestry University. 40(12): 111-113.

11. Wei Shan, Chengcheng Zhang, Ying Guo (2012) Mechanism of shallow slide on soil road cutting slope during spring in seasonal frozen region. Applied Mechanics and Materials Vols. 178-181: 1258-1263.

12. Ying Guo, Wei Shan et al. (2014) Landslide Mechanism and Shallow Soil Moisture of Soil Cut Slopes in Seasonally Frozen Regions. Engineering Geology for Society and Territory-Volume 1 Climate Change and Engineering Geology, Springer.

13. Chengcheng Zhang, Wei Shan et al. (2014) The Impact of the Shrub Roots on the Stability of Soil Cut Slope in Seasonal Frozen Regions-Landslide Science for a Safer Geoenvironment-Volume 3 Targeted Landslides, Springer (2014).

\section{IPL-167: Landslides Mechanism and the Subgrade Stability Controlling Measures in Island Permafrost Area (Duration: 2008-Now)}

\section{Project leader:}

Prof. Wei Shan, Cold Regions Science and Engineering, Northeast Forestry University, Harbin, China.

Core members of the Project:

Dr. Ying Guo, Northeast Forestry University, China

Dr. Hua Jiang, Northeast Forestry University, China

Dr. Chunjiao Wang, Northeast Forestry University, China

Dr. Zhaoguang Hu, Northeast Forestry University, China

\section{Objectives:}

The study area is located along the Bei-Hei Expressway Extension Project K160 K182 Section. Under the permafrost, landslides and other complex geological conditions investigations, design, construction and monitoring technical aspects of expressway expansion project.

Training Student: Two doctors, Three Masters

(1) Doctor Chunjiao Wang. Land surface deformation research of permafrost degradation area in northeast china based on D-InSAR (2015)

(2) Doctor Hua Jiang. Formation laws of the landslides and their effect on the subgrade stability in permafrost degradation region (2015)

(3) Master Qingbin Sun. BeiHei Expressway K178 +530 Landslide stability analysis (2012)

(4) Master Zhaoguang Hu. Movement mechanism of permafrost landslide based on gps and resistivity surveying (2012)

(5) Master Shuliang Zhang. The BeiHei black highway island permafrost degradation effect on subgrad stability research (2012)

(6) Master Wei Zhang. Bei'an-Heihe Expressway K177 +550 landslide section of experimental study of soil physical and mechanical indexes (2013)

\section{Publications}

1. Wei Shan, Zhaoguang Hu (2011) Application of Geological Drilling combined with High-density resistance in Island Structure Permafrost Survey. [2011 International Conference on Electronics Communications and Control. 08 1898-1904.

2. Wei Shan, Hua Jiang (2012) Formation Mechanism and Stability Analysis of Bei'an-Heihe Expressway Expansion Project K178 Landslide. Advanced Materials Research. 368-373: 953-958.

3. Wei Shan, Hua Jiang, Gaohang Cui (2012) "Formation Mechanism and Characteristics of the Bei'an to Heihe Expressway K177 Landslide" [C]. Advanced Materials Research. 422: 663-668.

4. Wei Shan, Hua Jiang et al. (2011) "Formation Mechanism and Characteristics of the Bei'an to Heihe Expressway K177 Landslide" Proceedings of the Second World Landslide Forum 3-7 October 2011, Rome.

5. Shan Wei, Jiang Hua et al. (2012) Island Permafrost Degrading Process and Deformation Characteristics of Expressway Widen Subgrade Foundation. Disaster Advances. Vol. 5 (4): 827-832.

6. Wei Shan, ChunJiao Wang et al. (2012) Expressway and Road Area Deformation Monitoring Research Based on 
InSAR Technology in Isolated Permafrost Area. Remote Sensing, Environment and Transportation Engineering (RSETE), 2nd International Conference. DOI:10.1109/ RSETE.2012.6260574.

7. Wei Shan, Zhaoguang et al. (2013) Mechanism of Permafrost Landslide Based on GPS and Resistivity Surveying. Progress of Geo-Disaster Mitigation Technology in Asia, Environmental Science and Engineering, DOI:10.1007/978-3-642-29107-4_18, Springer-Verlag.

8. Hua Jiang, Zhaoguang Hu, et al. (2013) Cut Layer Rocky Landslide Development Mechanism in Lesser Khingan Mountain. Progress of Geo-Disaster Mitigation Technology in Asia, Environmental Science and Engineering, DOI:10.1007/978-3-642-29107-4_19, Springer-Verlag.

9. Zhaoguang Hu; Wei Shan et al. (2014) The Deformation Monitoring of Superficial Layer Landslide in the Northern Part of Lesser Khingan Mountains of China. Engineering Geology for Society and Territory-Volume 1 Climate Change and Engineering Geology, Springer.

10. Hua Jiang; Wei Shan et al. (2014) Freeway Extension Project Island Permafrost Section Foundation Deformation Characteristics. Engineering Geology for Society and Territory-Volume 1 Climate Change and Engineering Geology, Springer.

11. Chunjiao Wang; Wei Shan et al. (2014) Permafrost Distribution Research Based on Remote Sensing Technology in Northwest Section of lesser Khingan Range in China. Engineering Geology for Society and Territory-Volume 1 Climate Change and Engineering Geology, Springer.

12. Wei Shan et al. (2014) Environment and Engineering Geology Problems in Permafrost Section of China Bei'an to Heihe Expressway under the Background of Climate Change. Engineering Geology for Society and Territory-Volume 1 Climate Change and Engineering Geology, Springer.

13. Zhaoguang Hu; Wei Shan et al. (2014) Landslide deformation monitoring and analysis of influence factors at $\mathrm{K} 178+530$ of the Bei'an to Heihe Expressway. Landslide Science for a Safer Geoenvironment-Volume 3 Targeted Landslides, Springer.

14. Hua Jiang; Wei Shan et al. (2014) Formation Mechanism and Deformation Characteristics of Cut Layer Rock Landslide in Island Permafrost Region. Landslide Science for a Safer Geoenvironment-Volume 3 Targeted Landslides, Springer.

15. Chunjiao Wang; Wei Shan et al. (2014) Permafrost Distribution Study Based on Landsat ETM+ Imagery of the Northwest Section of the Lesser Khingan Range, China.
Landslide Science for a Safer Geoenvironment-Volume 3 Targeted Landslides, Springer.

16. Wei Shan et al. (2014) The Impact of Climate Change on the Stability of Embankment and Slope of Bei'an Highway in Permafrost Regions. Landslide Science for a Safer Geoenvironment-Volume 1 The International Programme on Landslides (IPL), Springer.

17. Shan W, Hu Z, Guo Y (2015) The monitoring of soil pore water pressure and soil temperature in cutting slope before and after aufeis. Proceeding of the 68th Canadian Geotechnical Conference and 7th Canadian Permafrost Conference.

18. Shan W, Hu Z, Guo Y, Wang. C (2015). Environmental and Engineering Geology of the Bei'an to Heihe Expressway in China with a Focus on Climate Change, Engineering Geology for Society and Territory-Volume 1, DOI:10.1007/978-3-319-09300-0_51, Springer.

19. Shan W, Hu Z, Guo Y, Zhang C, Wang C, Jiang H, Liu Y, Xiao J (2015) The impact of climate change on landslides in southeastern of high-latitude permafrost regions of China. Front. Earth Sci. 3:7. doi:10.3389/ feart.2015.00007.

20. $\mathrm{Hu} \mathrm{Z}$, Shan W (2015) Landslide investigations in the northwest section of the lesser Khingan range in China using combined HDR and GPR methods. Bulletin of Engineering Geology and the Environment. Open access at Springerlink.com doi:10.1007/s10064-015-0805-y.

\section{IPL-203 New: Analysis and Identify of Landslides Based on Species Distribution and Surface Temperature Difference (Duration: 2016-Now)}

\section{Project leader:}

Dr. Ying Guo, Cold Regions Science and Engineering, Northeast Forestry University, Harbin, China.

Core members of the Project:

Dr. Ying Guo, Northeast Forestry University(NEFU), China Dr. Zhaoguang Hu, NEFU, China

Dr. Chunjiao Wang, NEFU, China

Dr. Cengcheng Zhang, NEFU, China

Dr. Hua Jiang, NEFU, China

\section{Objectives:}

In the Northeast high latitude permafrost zone of China, forest is extensively distributed, and landslide distribution is associated with tree species distribution. Using radar data and small UAV images, combined with manual investigation, to finally obtain landslide distributions within the whole forest area. 
Table 1 The members of the ICL landslides in cold regions network until August 2012

\begin{tabular}{|c|c|c|c|}
\hline ICL-CRLN Member Organization & Country & $\begin{array}{l}\text { ICL-CRLN Board } \\
\text { and Deputy Member }\end{array}$ & $\begin{array}{l}\text { ICL } \\
\text { Member }\end{array}$ \\
\hline Northeast Forestry University, China & China & Wei Shan, Ying Guo & Yes \\
\hline JSC "Hydroproject Institute", Russia & Russia & Alexander Strom & Yes \\
\hline $\begin{array}{l}{ }^{a} \text { Research Institute for Natural Hazards and } \\
\text { Disaster Recovery, Niigata University, Japan }\end{array}$ & Japan & Hideaki Marui & Yes \\
\hline${ }^{\mathrm{a}}$ Geological Survey of Canada & Canada & Baolin Wang & Yes \\
\hline $\begin{array}{l}{ }^{\mathrm{a}} \text { Department of Earth Sciences, University of } \\
\text { Firenze, Italy }\end{array}$ & Italy & Filippo Catani & Yes \\
\hline $\begin{array}{l}\text { Department of Geosciences, Shimane University, } \\
\text { Japan }\end{array}$ & Japan & Fawu Wang & No \\
\hline $\begin{array}{l}\text { College of Construction Engineering, Jilin } \\
\text { University, China }\end{array}$ & China & Lei Nie & No \\
\hline $\begin{array}{l}\text { College of Geology Engineering and Geomatics, } \\
\text { Chang'an University, China }\end{array}$ & China & Tonglu Li & No \\
\hline $\begin{array}{l}\text { Department of Geography, University of Zurich, } \\
\text { Switzerland }\end{array}$ & Switzerland & Stephan Gruber & No \\
\hline $\begin{array}{l}\text { Ministry of Forests, Lands and Natural Resource } \\
\text { Operations, Canada }\end{array}$ & Canada & Marten Geertsema & No \\
\hline Earth Cryosphere Institute SB RAS, Russia & Russia & Marina Leibman & No \\
\hline $\begin{array}{l}\text { Georadar Division, IDS Ingegneria Dei Sistemi S. } \\
\text { p.A. Italy }\end{array}$ & Italy & Paolo Farina & No \\
\hline
\end{tabular}

\section{ICL-CRLN and Its Outcome}

The International Consortium on Landslides (ICL) is an international non-governmental and non-profit scientific organization, which was established in January 2002 by worldwide universities, institutes, government organizations, academic societies and other entities. Now the ICL has 63 member institutions from 33 countries. The consortium promotes landslide research for the benefit of society and the environment, capacity building and education. At the 10th Session of ICL Board of Representatives, held in Rome, Italy on October 5, 2011, the ICL-Cold Region Landslides Network (ICL-CRLN) was established (Table 1).

The main goal of ICL-CRLN is to promote cooperation among scientists studying landslides in permafrost regions and regions with extreme weather conditions. It will support joint comprehensive investigations carried out by geographers, geologists, geocryologists and meteorologists from different countries and regions, study of landslide mechanisms, and distinguishing landforms, provision of landslide hazard assessment and elaboration of early warning systems. Such cooperation will enhance our understanding of hazardous phenomena in cold regions and, the safety of people living there and their properties and infrastructure. The following is detailed information on events. (a) Approved by Executive Director of ICL Prof. Kyoji Sassa, the first meeting was held of the ICL Landslides in Cold Regions Network (ICL-CRLN) and First Symposium on Landslides in Cold Regions in Harbin, China on July 23-27, 2012. In total, 51 scientists, technical experts and government officials from Canada, China, Italy, Japan and Russia attended the meeting and leading scientists presented academic reports. The meeting received 12 papers from five countries, which were edited and printed in a full color Proceedings "Landslides in Cold Regions in the Context of Climate Change" (ISSN 1431-6250), which was published by Springer after the meeting. The Meeting determined the purpose of the ICL-CRLN and set up the first Special Committee of ICL-CRLN as the executive body of ICL-CRLN. The meeting elected Prof. Wei Shan from Northeast Forestry University, China as the ICL-CRLN Special Committee Chairman, and elected Dr. Alexander Strom from Geodynamic Research Center, Russia, and Dr. Hideaki Marui from Niigata University, Japan as vice-chairmen of the Special Committee. The Meeting determined the official secretariat of the ICL-CRLN, located at the Northeast Forestry University, China, that has the responsibility of necessary operations and management (Fig. 4). 

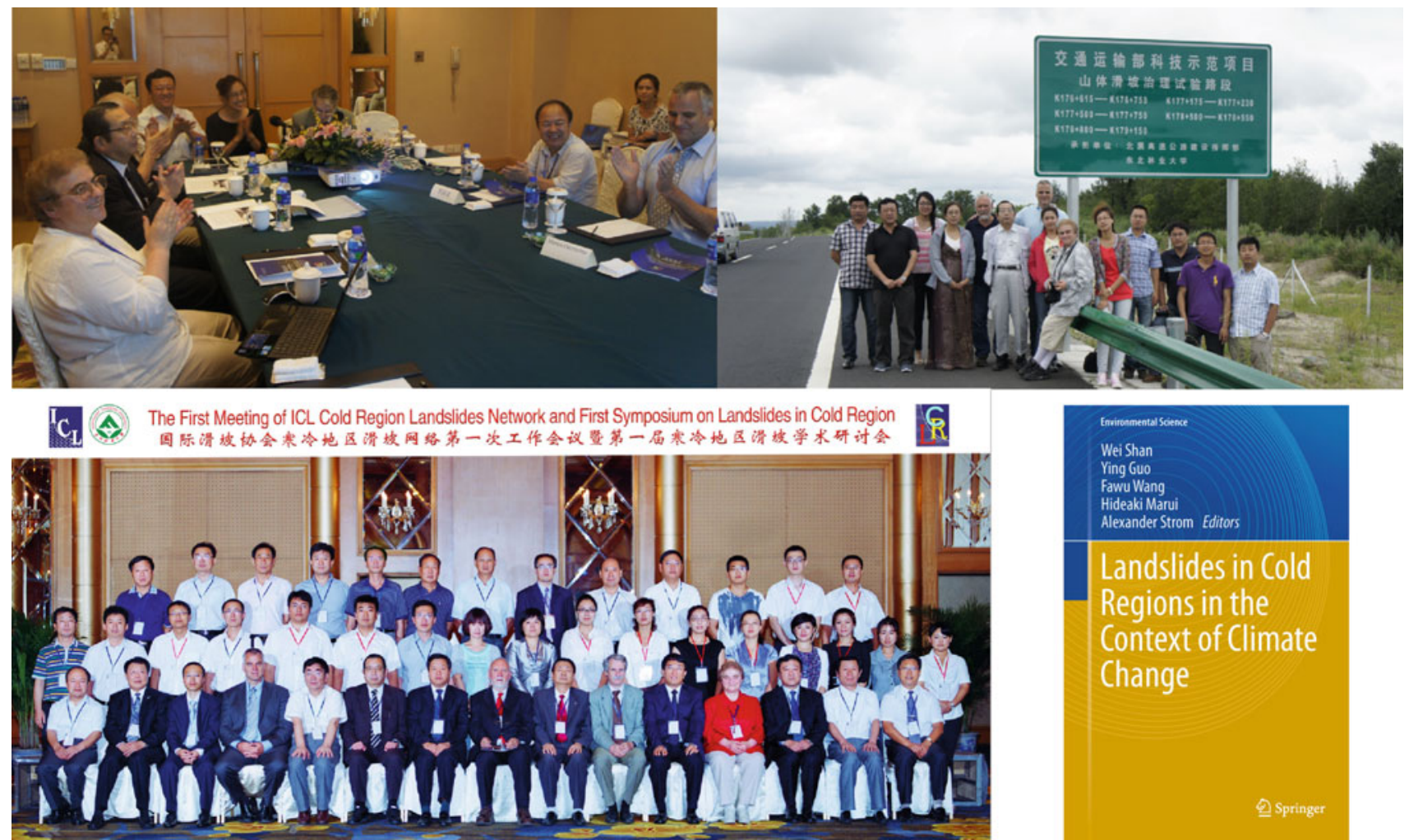

Fig. 4 The first meeting of ICL-CRLN (Harbin, China, July 2012)

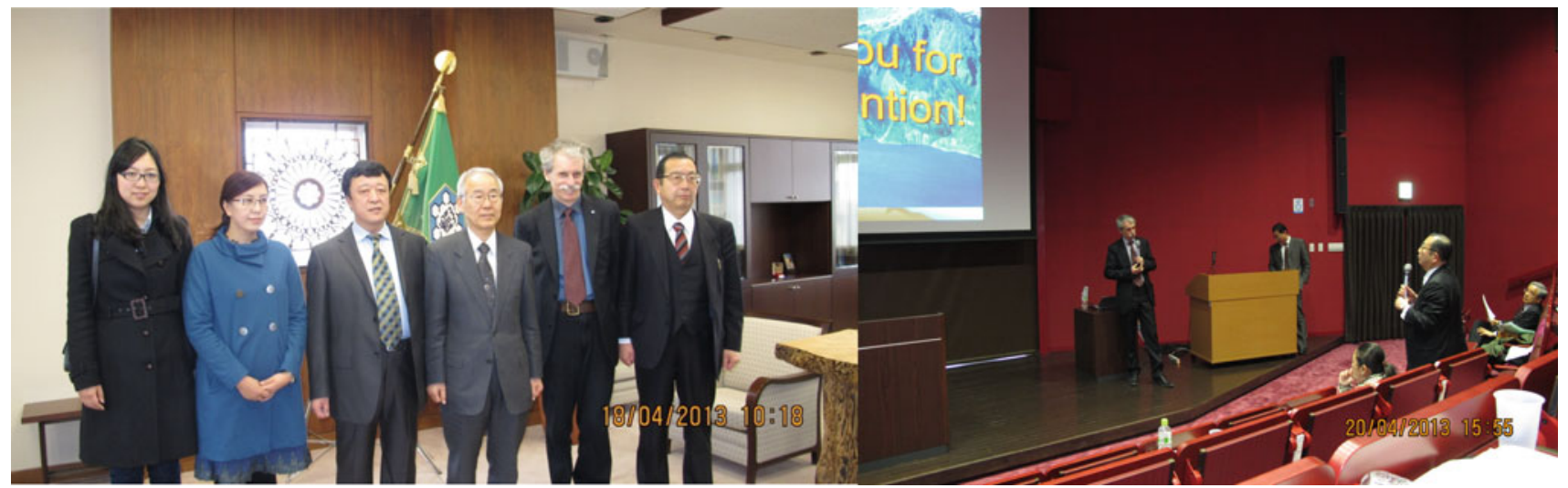

Fig. 5 Intention of cooperating with Niigata University on landslides caused by snowfall

(b) There is an intention to cooperate with the Research Institute for Natural Hazards and Disaster Recovery, Niigata University, Japan, with a focus on the landslides causing by snowfall (Fig. 5).

(c) In early June, 2014, Dr. Ying Guo, as the convener, hosted C7 session "Landslide in Cold Regions" at the Third World Landslide Forum in Beijing. The session received 16 papers, and made 7 oral reports. The second ICL-CRLN meeting was held during the Third World Landslide Forum. The papers of the C7 session (16 papers) were published in 3nd World Landslide Forum Proceeding, Landslide Science for a Safer Geoenvironment - Volume 3 Targeted Landslides (Springer, ISBN 978-3-319-04995-3). Dr. Ying Guo is the editor of Part 7 of this book (Fig. 6). 


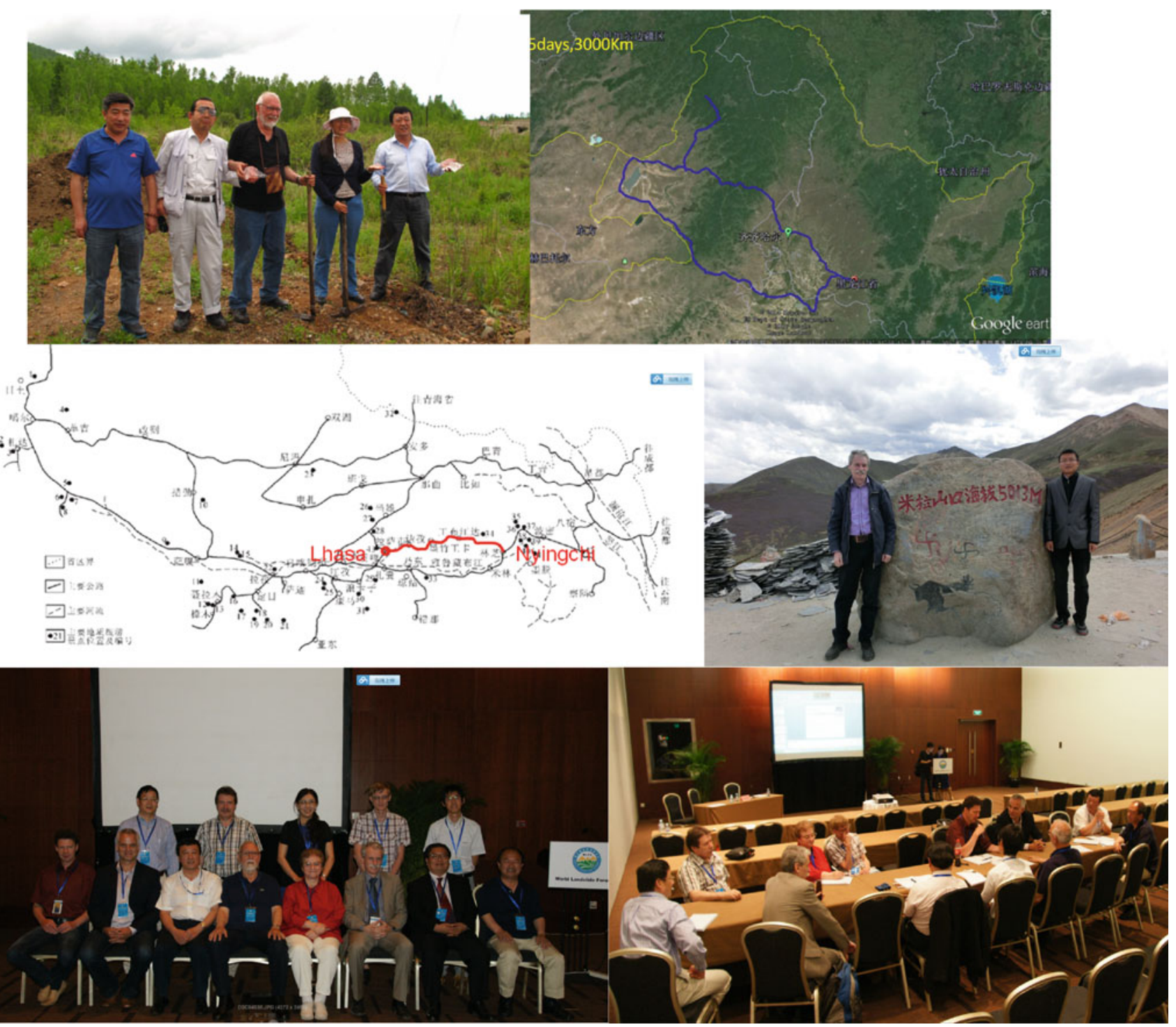

Fig. 6 The 2nd meeting of ICL-CRLN and the c7 session of WLF3, Beijing (June, 2014)

(d) On 13-14 September, 2014, Prof. Wei Shan visited Florence University, and signed a "Memorandum of Understanding for Academic Cooperation and Exchange Between the Department of Earth Sciences of the University of Florence, Italy and the Institute of Cold Regions Science and Engineering of Northeast Forestry University, China." The two colleges will cooperate in joint training of graduate students and on permafrost distribution, the impact of permafrost degeneration on landscape change and so on. This cooperation will combine field survey data, monitoring data with spacebourne radar data, which maybe open a new milestone for the study of landforms and environmental change in high-latitude permafrost regions (Fig. 7).

(e) Prof. Wei Shan and Dr. Ying Guo attended Geological Society of America (GSA) Annual Meeting held 19-22 October 2014 in Vancouver, Canada, and made two poster reports.

(f) On 14-18 March 2015, Prof. Wei Shan attended the Third World Conference on Disaster Risk Reduction (WCDRR) organized in Sendai, Japan, and attended "Sendai Partnerships 2015-2024 for Global Promotion 


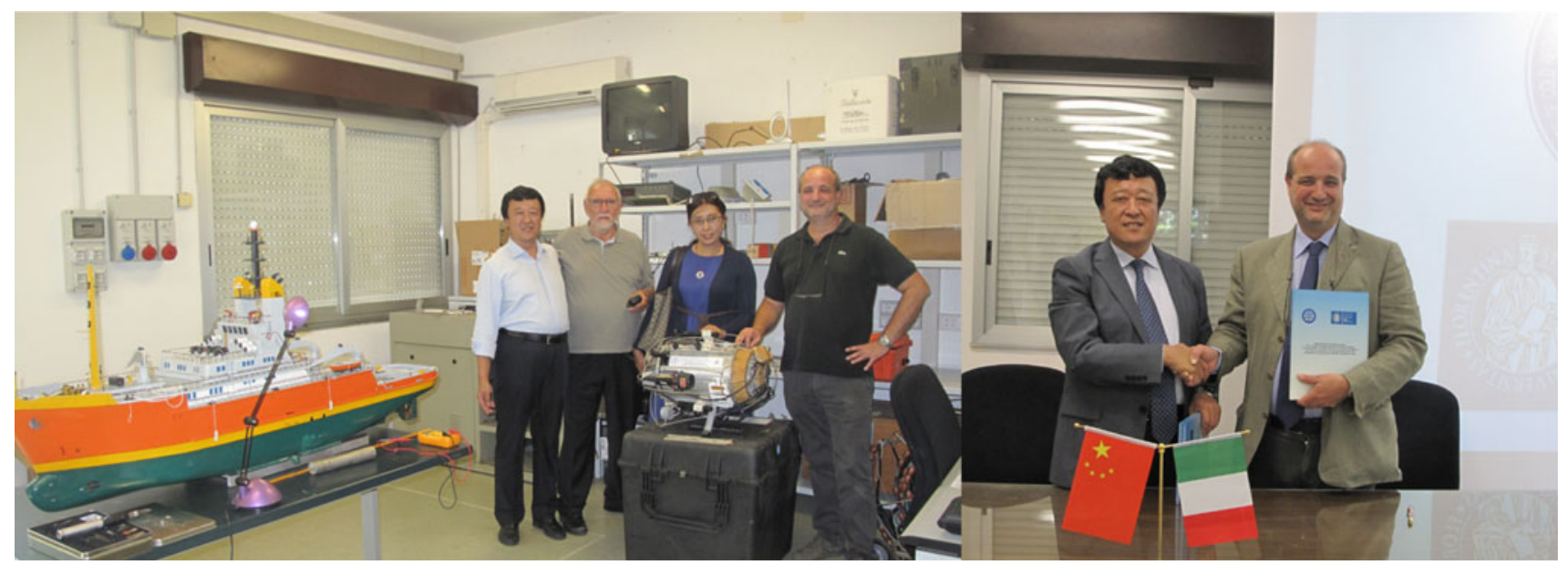

Fig. 7 Memorandum of understanding for academic cooperation and exchange with Florence University

of Understanding and Reducing Landslide, Flood and Tsunami Disaster Risk".

(g) With Network member Dr. Bailin Wang, Prof. Wei Shan attended the 68th Canadian Geotechnical Conference and 7th Canadian Permafrost Conference (Quebec, 20-25 Sept 2015) and made an oral report "The monitoring of soil pore water pressure and soil temperature in cutting slope before and after aufeis".

(h) Attended ICL-IPL Kyoto Conference 2016 in March 2016, making preparations for ISDR-ICL Landslide Teaching Tools and WLF4-Session 5.2 (Landslides in natural environment).

\section{Publications}

1. Ying Guo, Paolo Canuti, et al. (2012) The First Meeting of ICL Landslides in Cold Regions Network, Harbin, Landslides, DOI 10.1007/s10346-012-0369-x.

2. Giorgio Lollino, Andrea Manconi, John Clague, Wei Shan, Marta Chiarle. Engineering Geology for Society and Territory-Volume 1 Climate Change and Engineering Geology, Part V (Environmental and engineering geological problems in permafrost regions in the context of a warming climate. 21 papers) Springer, ISBN 978-3-319-09299-7 ISBN 978-3-319-09300-0 (eBook) DOI 10.1007/978-3-319-09300-0.

3. Kyoji Sassa, Paolo Canuti, Yueping Yin. Landslide Science for a Safer Geoenvironment-Volume 3 Targeted Landslides, Part VII (Landslide in Cold Regions, 16 papers) Springer, ISBN 978-3-319-04995-3 ISBN 978-3-319-04996-0 (eBook) DOI 10.1007/978-3-31904996-0.
4. Kyoji Sassa, Paolo Canuti, Yueping Yin. Landslide Science for a Safer Geoenvironment-Volume 1, Part II (1 paper). The International Programme on Landslides (IPL), Springer, ISBN 978-3-319-04998-4 ISBN 978-3-319-04999-1 (eBook) DOI 10.1007/978-3-31904999-1.

5. Shan W, Hu Z, Guo Y (2015)The monitoring of soil pore water pressure and soil temperature in cutting slope before and after aufeis. Proceedings of the 68th Canadian Geotechnical Conference and 7th Canadian Permafrost Conference, Sept 2015.

6) Wei Shan, Ying Guo, Fawu Wang, Hideaki Marui, Alexander Strom Landslides in Cold Regions in the Context of Climate Change. Springer, ISSN 1431-6250. ISBN 978-3-319-00866-0 ISBN 978-3-319-00867-7 (eBook) DOI 10.1007/978-3-319-00867-7.

\section{WCoE and Its Outcome}

Based on the research results of IPL projects and the help of ICL-CRLN, the Institute of Cold Regions Science and Engineering, North East Forestry University, China. proposed to IPL-GPC to build a Research Center of Cold Regions Landslide and it was approved. The following work has been carried out since the center was established.

(a) At the opening Ceremony of WLF3, "Research Center of Cold Regions Landslide, China." has been approved and designated as a "World Centre of Excellence on landslide disaster reduction, 2014-2017'. Prof. Wei Shan, the leader of our network was approved, as the leader of IPL Award for success for IPL project. 


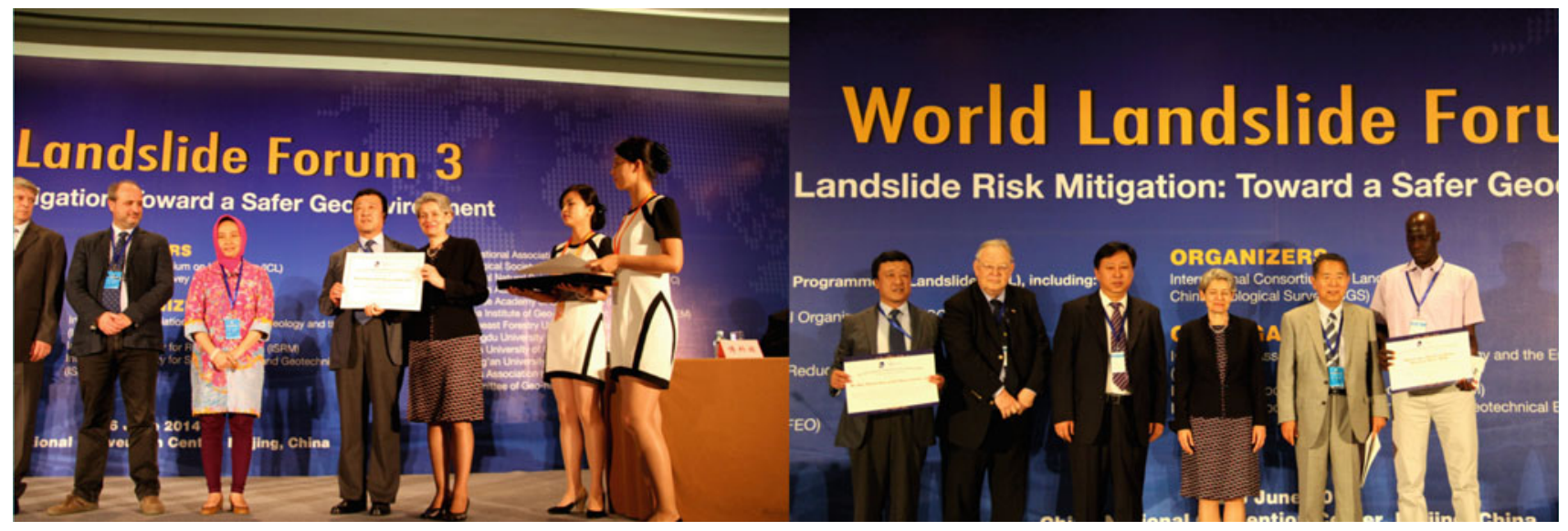

Fig. 8 WCoE approved as "World Centre of Excellence on landslide disaster reduction, 2014-2017" and Prof. Wei Shan presented with an IPL Award for success for IPL project
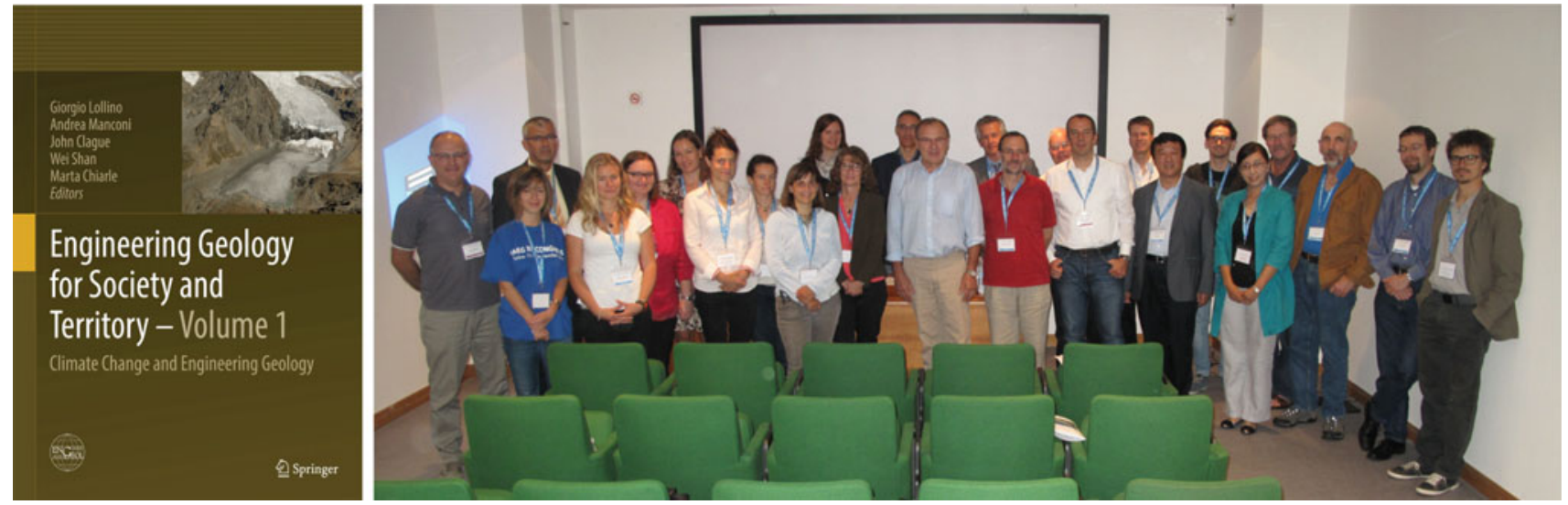

Fig. 9 Session of IAEG XII Congress in Turin, Italy

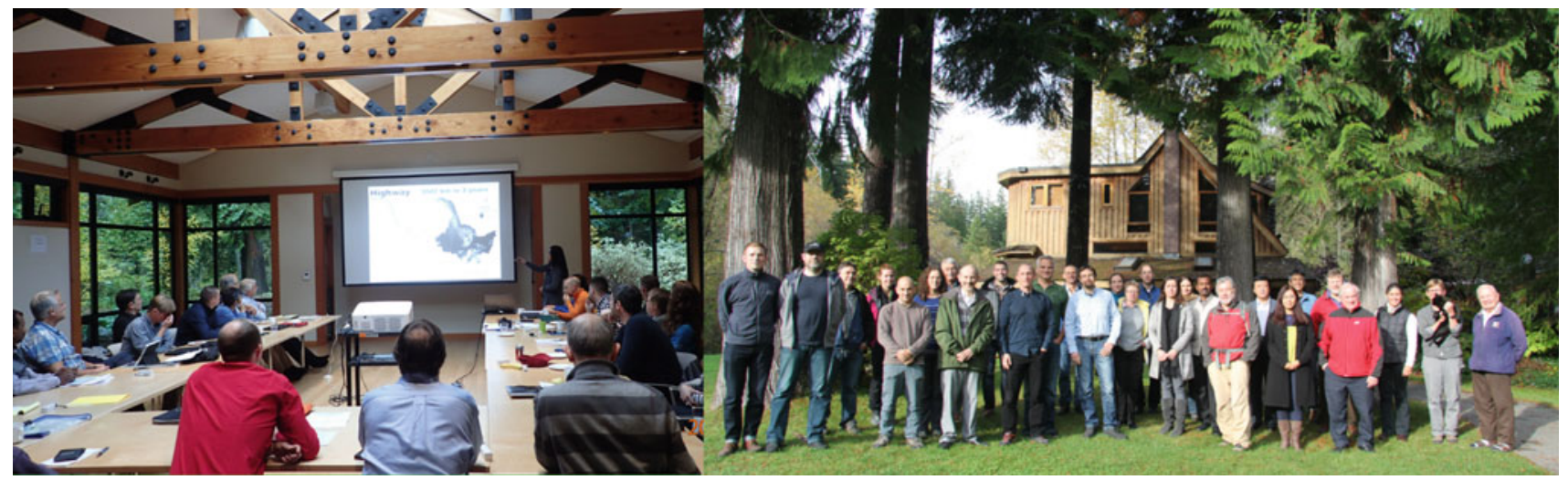

Fig. 10 Workshop: Impacts of permafrost thaw in mountainous areas of Canada and beyond 


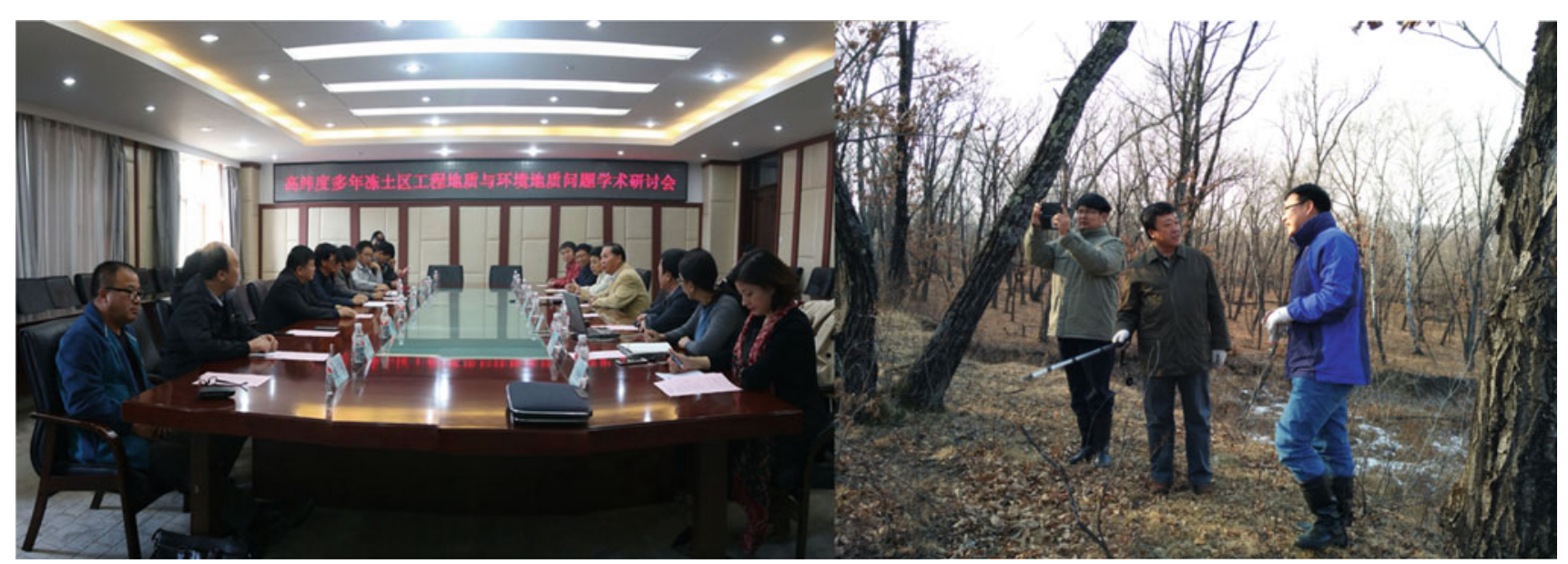

Fig. 11 Academic cooperation and exchange with Chinese researchers

UNESCO Director-General Irina Bokova presented the award personally (Fig. 8).

(b) On September 16, 2014, while participating in IAEG XII Congress, held in Turin, Italy, Prof. Wei Shan convened and presided over session 1.9 on "Environmental and engineering geological problems in permafrost regions in the context of a warming climate" and received 21 papers. Professor Wei Shan, as a convener and compiler of a conference papers volume, was rewarded by Professor Giorgio Lollino, the President of the Assembly. The papers of session 1.9 (21 papers) was published in IAEG XII Congress Proceeding, Engineering Geology for Society and Territory-Volume 1 Climate Change and Engineering Geology (Springer, ISBN 978-3-319-09299-7). Prof. Wei Shan is one of the editors of this book (Fig. 9).

(c) On 22-25 October, 2014, Prof. Wei Shan and Dr. Ying Guo attended the Workshop "Impacts of permafrost thaw in mountain areas" organized by the Canadian Engineering Research Council (NSERC), the Canadian Forest Service and Ottawa University, to gain more knowledge of permafrost research in Canada. 25 people attended the meeting, which included academics from Canada (Geological Survey of Canada, University of British Columbia, Ottawa University, Carleton University), engineers from Canada, and foreign experts (Washington State University, Zurich University). Prof. Shan and Dr. Guo Ying, attended as foreign experts and representatives of ICL-CRLN. Each expert described relevant research reports from their own academic point of view, these report covered detection technology, theory methods, management, public awareness, databases and other aspects (Fig. 10). (d) ICL-CRLN reached a cooperation agreement on joint research with CAREERI (Cold and Arid Regions Environmental and Engineering Research Institute, CAS.); Nanjing Institute of Geography and Limnology, CAS.; Beijing Institute of Geographic Science and Natural Resources Research, CAS. They will focus on landslides in high latitude permafrost regions in the context of climate change (Fig. 11).

\section{Prospects}

At the 3rd United Nations World Conference on Disaster Risk Reduction in Sendai, Japan in March 14-18, 2015, the ICL proposed the ISDR-ICL Sendai Partnerships 2015-2025 for Global Promotion of Understanding and Reducing Landslide Disaster Risk. It was accepted and signed by 16 United Nations and international stakeholders, and national organizations in 2015. For the effective implementation of "The Sendai Partnerships 2015-2025" cooperation work, at ICL-IPL Kyoto Conference 2016, ICL called for ICL Networks and IPL-WCoE to strengthen concrete collaboration within regional ICL members, as well as collaboration within non-ICL organization. The forms could be bilateral and multilateral project, thematic workshops and conferences, courses and summer schools, life-long learning, training, papers, brochures, proceedings, books and so on.

Based on the above activity plan, "ICL-CRLN" and "IPL-WCoE" will further strengthen exchanges between members of the network, as well as promote the development of cold regions landslide research, also make 
preparations for 4th World landslide Forum to be held in Slovenia in 2017.

\section{References}

Ballantyne CK, Sandeman GF, Stone JO, Wilson P (2014) Rock-slope failure following Late Pleistocene deglaciation on tectonically stable mountainous terrain. Quatern Sci Rev 86:144-157

Blunden J, Arndt DS (2011) State of the climate in 2011. In: American Meteorological Society (http://www.ncdc.noaa.gov/bams-state-ofthe-climate/)

Eu-Fp7 (2008) ACQWA: Assessing climate impacts on the quantity and quality of water-a large integrating project under EU Framework Programme 7 (FP7), A summary for policymakers. (www.acqwa.ch)

Fischer L, Hugge C, Kääb Haeberli W (2013) Slope failures and erosion rates on a glacierized high-mountain face under climatic changes Earth Surf. Process Land 38:836-846. doi:10.1002/esp. 3355

Grab SW, Linde JH (2014) Mapping exposure to snow in a developing African context: implications for human and livestock vulnerability in Lesotho. Nat Hazards 71:1537-1560. doi:10.1007/s11069-0130964-8

Guo Y, Canuti P, Strom A, Hideaki M, Shan W (2013) The first meeting of ICL landslides in cold regions network, Harbin, 2012. Landslides 10:99-102. doi:10.1007/s10346-012-0369-x

Haeberli W (2013) Mountain permafrost - research frontiers and a special long-term challenge. Cold Reg Sci Technol 96:71-76

ICL (International Consortium on Landslides) (2012) International consortium on landslides strategic plan 2012-2021 - to create a safer geo-environment. (http://iplhq.org/category/home/)

ICL (2014) The 2014 Beijing declaration landslide risk mitigation: toward a safer geo-environment (http://iplhq.org/category/home/)
IPCC (Intergovernmental Panel on Climate Change) (2007) Summary for policymakers. Climate change 2007: the physical science basis. Contribution of working group I to the fourth assessment report of the intergovernmental panel on climate change. Cambridge University Press, Cambridge

IPCC (2013) Summary for policymakers. Working group I contribution to the IPCC Fifth assessment report climate change 2013: the physical science basis. Cambridge University Press, Cambridge

Kliem P, Buylaert JP, Hahn A, Mayrd C, Murray AS, Ohlendorf C, Veres D, Wastegård S, Zolitschka B, Team TPS (2013) Magnitude, geomorphologic response and climate links of lake level oscillations at Laguna Potrok Aike, Patagonian steppe. Quatern Sci Rev 71:131-146

Nussbaumer S, Schaub Y, Huggel C, Nat AW (2014) Risk estimation for future glacier lake outburst floods based on local land-use changes. Hazards Earth Syst Sci 14:1611-1624. doi:10.5194/nhess14-1611-2014

Shan W, Guo Y, Wang F, Marui H, Strom A (2014a) Landslides in cold regions in the context of climate change. Environmental Science and Engineering. Springer, Berlin. ISBN 978-3-319-00866-0. ISBN 978-3-319-00867-7 (eBook). doi:10.1007/978-3-319-00867-7

Shan W, Guo Y, Zhan C, Hu Z, Jiang H, Wang C (2014b) Climate-change impacts on embankments and slope stability in permafrost regions of Bei'an-Heihe Highway. Landslide Sci Safer Geoenviron 1:155-160. doi:10.1007/978-3-31904999-1_18

Starnberger R, Drescher SR, Reitner JM, Rodnight H, Reimer PJ, Spötl C (2013) Late Pleistocene climate change and landscape dynamics in the Eastern Alps: the inner-alpine Unterangerberg record (Austria). Quatern Sci Rev 68:17-42

Stoffel M, Tiranti D, Huggel C (2014) Climate change impacts on mass movements - case studies from the European Alps. Sci Total Environ 2014:1255-1266 
Open Access This chapter is licensed under the terms of the Creative Commons Attribution 4.0 International License (http:// creativecommons.org/licenses/by/4.0/), which permits use, sharing, adaptation, distribution and reproduction in any medium or format, as long as you give appropriate credit to the original author(s) and the source, provide a link to the Creative Commons license and indicate if changes were made.
The images or other third party material in this chapter are included in the chapter's Creative Commons license, unless indicated otherwise in a credit line to the material. If material is not included in the chapter's Creative Commons license and your intended use is not permitted by statutory regulation or exceeds the permitted use, you will need to obtain permission directly from the copyright holder. 